\title{
PARADIGMA KEILMUAN ISLAM DI PERGURUAN TINGGI
}

\author{
Oleh: Sun Choirol Ummah \\ Sunchoirolummah@uny.ac.id
}

\begin{abstract}
ABSTRAK
Sains dan agama selayaknya dapat dipersandingkan bahkan keduanya seyogyanya mampu bersinergi dan saling mengisi. Di sisi lain, ada kegamangan di antara para ilmuwan yang menganggap bahwa perangkat metodologis dalam ilmu pengetahuan tidak bisa diterapkan dalam kajian keagamaan, atau menganggap bahwa nilai-nilai agama tidak bisa membantu para saintis untuk menemukan kebenarannya. Dalam hal ini ada yang masih memandang bahwa keduanya (ilmu dan agama) merupakan single entity atau diposisikan sebagai isolated entities. Antitesis keduanya terlihat pada model interconnected entities sebagai cara pandang yang lebih maju yang menyentuh persoalan pendekatan (approach) dan metode berfikir serta penelitian (process and procedure).

Ada empat tipologi hubungan sains dan agama yang sering muncul diantaranya; konflik, independen, dialog, dan integrasi. Tipologi terkini yang banyak digunakan yakni integrasi yang dikombinasikan dengan interkoneksi. Selayaknya perguruan tinggi yang ada di Indonesia berupaya keras untuk mendekatkan, mengintegrasikan dan mengoneksikan antara sains dan agama sehingga nilai-nilai kehidupan yang berada pada wilayah makna (agama) dan ingin dituju bisa tercapai.
\end{abstract}

Kata kunci: paradigma keilmuan, sains, agama

\begin{abstract}
Science and religion should be able to be competed even if they should be able to work together and complement each other. On the other hand, there is unease among scientists who consider that methodological tools in science cannot be applied in religious studies, or assume that religious values cannot help scientists find the truth. In this case there are those who still view that both (science and religion) are single entities or positioned as isolated entities. The antithesis of both is seen in the interconnected entities model as a more advanced perspective that touches on the problem of approaches and methods and procedures.

There are four typologies of the relationship between science and religion that often arise including; conflict, independence, dialogue and integration. The most recent typology that is widely used is integration combined with interconnection. It is appropriate for universities in Indonesia to strive to get closer, integrate and connect between science and religion so that the values of life that are in the area of meaning (religion) and want to be achieved can be achieved.
\end{abstract}

Keywords: scientific paradigm, science, religion 


\section{PENDAHULUAN}

Banyak di kalangan masyarakat muslim yang masih meragukan kemampuan ilmu (science) untuk berpadu dengan agama (religion). Bahkan ada kecenderungan bahwa ilmu pengetahuan modern semakin mengambil jarak dari agama. Keilmuan yang jauh dari agama secara sekuler telah diwariskan gereja selama berabad-abad. Dalam pandangan Ismail Raji al-Faruqi, paradigma sekuler semacam ini telah menyebabkan sains modern menjadi kering tak bermakna, bahkan terpisah sama sekali dari doktrin dan monotheisme (tauhid) yang tercermin dalam lima kesatuan, meliputi kesatuan Tuhan, kesatuan alam, kesatuan kebenaran, kesatuan hidup, dan kesatuan umat manusia (Al-Faruqi, 1995: 55-95).

Dengan bahasa lain, Amin Abdullah juga melihat adanya kegamangan dari sementara kalangan untuk memadukan antara ilmu dan agama. Dalam hal ini ada yang masih memandang bahwa keduanya (ilmu dan agama) merupakan single entity dalam artian pengetahuan agama berdiri sendiri tanpa memerlukan bantuan metodologi yang digunakan oleh ilmu pengetahuan umum dan begitu pula sebaliknya. Kalaupun tidak demikian, antara keduanya diposisikan sebagai isolated entities dalam arti masingmasing rumpun ilmu berdiri sendiri atau, tahu keberadaan rumpun yang lain tetapi tidak bersentuhan dan bertegur sapa secara metodologis (Abdullah, 2007: 10). Albert Einstein (Mulyanto, 2006) yang mengusung konsep keterkaitan agama dan sains juga menyinggung sebagai hal yang tidak bisa dipisahkan antara satu dengan lainnya dengan ungkapan "Science without religion is lame, religion without science is blind" (bahwa ilmu pengetahuan tanpa agama lumpuh dan agama tanpa ilmu pengetahuan akan buta).

Cara pandang yang lebih maju nampaknya terlihat pada model interconnected entities, yaitu masingmasing sadar akan keterbatasannya dalam memecahkan persoalan manusia, lalu menjalin kerjasama setidaknya dalam hal yang menyentuh persoalan pendekatan (approach) dan metode berfikir serta penelitian (process and procedure) (Abdullah, 2007: 10).

\section{Pandangan Roston}

Roston tampaknya merasakan hal yang sama. Melalui kajiannya tentang metode dalam penyelidikan ilmiah dan agama, Roston mengungkapkan bahwa fenomena menyampingkan agama dalam kajian-kajian ilmiah itu benar-benar terjadi. Begitu pula sebaliknya mengisolasi diskursus agama dari studi-studi ilmiah itu juga banyak dilakukan orang. Menurut 
Roston ada kecenderungan para ilmuwan dan pemikir agama yang memisahkan nilai-nilai etis keagamaan dalam kajian ilmu pengetahuan dan sebaliknya mereka memahami agama dengan menyampingkan perangkat metodologis dalam ilmu pengetahuan umum. Selain itu, mereka pada umumnya juga menganggap bahwa perangkat metodologis dalam ilmu pengetahuan tidak bisa diterapkan dalam kajian keagamaan, atau menganggap bahwa nilai-nilai agama tidak bisa membantu para saintis untuk menemukan kebenarannya (Roston, 2006:1-2).

Menurut Roston alur pikir yang logis antara ilmu pengetahuan dan agama jika dikonstruk dengan baik pada umumnya akan dapat bertemu pada satu titik persamaan. Hal ini dengan sendirinya akan mematahkan cara pandang kaum positivis dan kebanyakan saintis mengenai alam metafisis. Lebih lanjut Roston menegaskan bahwa logika kaum positivis dan saintis yang selalu bertolak dari eksistensi material-empirik (Mustofa, 2007: 233) yang kemudian diolah secara ilmiah melalui observasi, identifikasi deskripsi, investigasi eksperimental dan teoritisasi (Ahmad, 2008: 73) tersebut sering merendakan agama serta logikanya. Hal ini menurutnya merupakan kesalahan besar yang tidak bisa dibiarkan. Poin penting dan menarik dari penelitian Roston yakni kemampuannya mengeksplorasi cara kerja metodik dalam penelitian ilmiah (natural, sosial, and humanities science) dan agama serta mencari titik persamaan serta perbedaan antara keduanya. Menurut Roston metode ilmiah memiliki cara kerja yang unik dan sejarah perkembangan yang kompleks. Ia menggabungkan antara observasi, metode, dan kesimpulan. Meskipun demikian, proses penggabungan ini terkadang menghasilkan sesuatu yang anomali serta mengandung kemungkinan untuk benar atau salah. Di satu sisi memang cara kerja ilmu pengetahuan bersifat induktif (Roston, 2006: 4) (terutama untuk menemukan teori awal), namun di sisi lain ia juga merupakan hipotesis-deduktif dalam rangka menguji dan membuktikan validitas teori pertama yang harus dibenarkan atau disangkal.

Poin-poin penting pemikiran Roston, pertama, sama halnya dengan ilmu pengetahuan umum, agama menurut Roston juga menggabungkan unsur pengalaman, teori dan kesimpulan secara metodis (Roston, 2006: 9). Sebelum seorang ilmuwan atau ahli agama menghasilkan sebuah kesimpulan tentang objek yang dikajinya, terlebih dahulu teori yang digunakan harus diuji, baik secara eksperimental (dalam ilmu pengetahuan) atau eksperiensial (dalam agama) (Wasim, 2000: 101). Kedua, teori yang berkembang 
baik dalam ilmu pengetahuan maupun agama selalu terkait dengan paradigma tertentu. Dalam kondisi yang kurang baik, paradigma tersebut bisa berubah menjadi ideologi atau sebuah "blik" yang menghegemoni suatu pengalaman dengan teori tertentu. Menurut Roston, paradigma yang baik yakni paradigma yang selalu mereformasi diri dan tidak memaksakan cara pandangnya pada lingkup pengalaman yang tidak memiliki tendensi dan korelasi dengannya (Roston, 2006:11-12).

Ketiga, Roston berhasil membuktikan bahwa baik agama maupun ilmu pengetahuan sama-sama mengakui peran sentral seorang ilmuwan maupun pemikir agama yang berdedikasi. Peran partisipatif mereka sangat diperlukan dalam upaya menggali nilai-nilai universal dalam ilmu pengetahuan maupun agama. Pada wilayah universalitas inilah antara ilmu pengetahuan dan agama dapat bertemu (Roston, 2006: 22-32). Keempat, meskipun logika yang dipakai dalam ilmu pengetahuan cenderung berorientasi pada aspek kausalitas (sebab) dan agama lebih berorientasi pada aspek makna, namun keduanya sangat mungkin dipadukan. Sebab, apabila ilmu pengetahuan hanya dibatasi pada penjelasan yang bersifat kausal, maka ia tidak akan pernah menentukan nilai-nilai dalam kehidupan. Untuk itu, ilmu pengetahuan harus bersedia menyapa agama agar nilai-nilai kehidupan yang ingin dituju bisa tercapai. Nilai-nilai kehidupan selalu berada pada wilayah makna dan makna itu sendiri menjadi bagian dari agama (Roston, 2006: 33-46).

Berbicara lebih lanjut tentang poin kedua dari pemikiran Roston bahwa dalam ilmu pengetahuan maupun agama selalu terkait dengan paradigma tertentu. Penggunaan paradigma yang sederhana diilustrasikan dengan gambar dua sisi wanita muda dan wanita tua yang buruk rupa, seperti gambar di bawah.

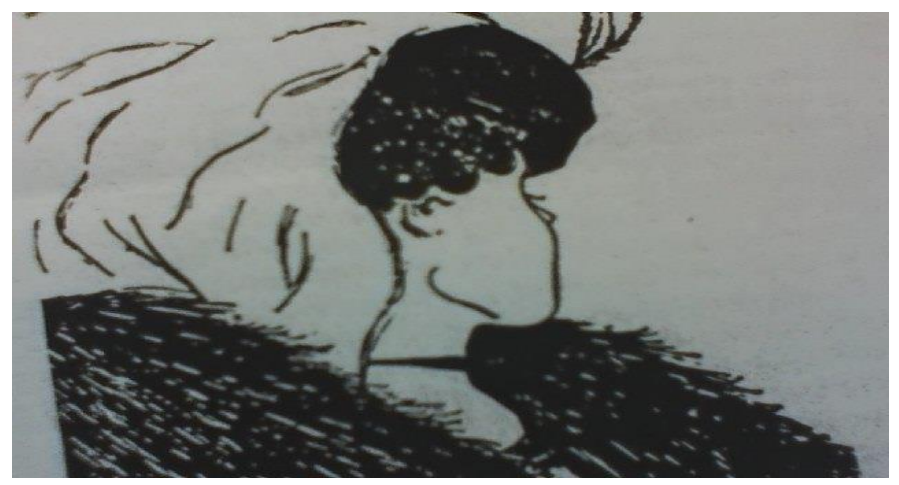

Gambar 1. Gambar dua sisi wanita muda-wanita tua yang buruk rupa (Roston, 2006) 
Setelah mengamati gambar di atas, paradigma seseorang dapat dilihat pertama, para pengamat tidak melihat kecuali dengan pandangan yang salah hanya garis-garis hitam putih dan bidang yang kecil, data mentah, tetapi sekarang melihat seorang wanita muda dan kemudian seorang wanita tua yang buruk rupa. Ada garis tertentu yang menentukan sebuah kalung atau mulut. Atau garis lainnya yang merupakan hidung atau dagu, tergantung pada gestalt (Roston, 1987: 12). Kedua, pada skala yang lebih luas, ilmu pengetahuan dan agama menyediakan jaringan berbeda yang bisa memetakan dunia, tetapi sejauh mana mereka saling melengkapi dan sejauh mana ketidaksepadanan itu tidak teramati dengan mudah. Oleh karena itu, kehatihatian terhadap sebuah anggapan dasar perlu dikontrol agar masing-masing tidak bersikap tendensius.

Sikap subjektifitas harus diimbangi dengan penerimaan paradigma yang bersifat kolektif, tidak hanya individual. Perlu disadari bahwa sebuah paradigma individual harus dicuci dalam kawah candradimuka, diperdebatkan, diselidiki, dan diuji, tidak hanya tergantung pada perasaan seseorang tetapi pada kapasitas seseorang untuk meyakinkan yang lain dan untuk mempertahankan integritas komunitas yang ini disebut dengan paradigma intersubjektif. Dalam gambar di atas menunjukkan teori dan keyakinan tumbuh dan berkembang. Epistemik gestalt ini bergantian satu sama lain dalam sejarah, sehingga dalam kenyataannya kita tidak mempunyai gambar yang diam tetapi gambar yang bergerak, sebuah cerita, sebuah naratif yang hidup seperti pada perkembangan ilmu pengetahuan dan agama. Teori dan keyakinan yang lama kadang dihapuskan, dianggap tidak koheren dan dilupakan, tetapi terkadang digunakan lagi dan dipertahankan dalam gestalt yang ditransformasi.

Beberapa sistem agama memberikan bermacam-macam keyakinan untuk melihat signifikansi kehidupan di dunia. Seperti pada gambar di atas, perbedaan paradigma tersebut muncul karena sensitivitas pengamatan yang tergantung pada tingkah laku, pengalaman dan karakternya. Selanjutnya, sebagian gestalt ini tumpang tindih, tetapi akhirnya tidak dapat dibandingkan. Umat Budha Therapada dan umat Kristen setuju dengan anggapan bahwa 
kehidupan sebagai sesuatu yang suci dan dihormati, tetapi mereka tidak menyetujui anggapan dunia sebagai sebuah ciptaan Tuhan sendiri atau sebagai sebuah matriks tidak tentu asalusulnya. Baik di dalam ilmu pengetahuan atau dalam agama ada keharusan untuk mengikuti semua fakta yang tepat, tetapi menggeser fakta ini menjadi paradigma yang paling dapat dipercaya tidak mudah. Kadangkadang diperlukan pengabaian secara bijaksana terhadap fakta yang janggal tersebut dan kadang-kadang fakta tersebut adalah fakta yang pada awalnya ditolak tetapi kemudian terbukti secara serius menggulingkan teori tersebut.

\section{Teori Gestalt}

Teori Gestalt pada awalnya berasal dari bahasa Jerman yang mempunyai padanan arti sebagai "bentuk atau konfigurasi." Pokok pandangan dalam Gestalt bahwa obyek atau peristiwa tertentu akan dipandang sebagai sesuatu keseluruhan yang terorganisasikan. Koffka dan Kohler berpendapat bahwa ada tujuh prinsip organisasi yang terpenting (Gredler, 1991: 58) yaitu: (a) hubungan bentuk dan latar (figure and ground relationship) yang menganggap bahwa setiap bidang pengamatan dapat dibagi dua yaitu figure (bentuk) dan latar belakang. Penampilan suatu objek seperti ukuran, potongan, warna dan sebagainya membedakan figure dari latar belakang. Bila figure dan latar bersifat samar-samar, maka akan terjadi kekaburan penafsiran antara latar dan figure, (b) kedekatan (proximity) menjelaskan bahwa unsurunsur yang saling berdekatan (baik waktu maupun ruang) dalam bidang pengamatan akan dipandang sebagai satu bentuk tertentu, (c) kesamaan (similarity) bahwa sesuatu yang memiliki kesamaan cenderung akan dipandang sebagai suatu obyek yang saling memiliki, (d) arah bersama (common direction) bahwa unsur-unsur bidang pengamatan yang berada dalam arah yang sama cenderung akan dipersepsi sebagi suatu figure atau bentuk tertentu, (e) kesederhanaan (simplicity) bahwa orang cenderung menata bidang pengamatannya bentuk yang sederhana, penampilan reguler dan cenderung membentuk keseluruhan yang baik berdasarkan susunan simetris dan keteraturan, dan (f) ketertutupan (closure) bahwa orang cenderung akan mengisi kekosongan 
suatu pola obyek atau pengamatan yang tidak lengkap.

Implikasi dalam studi agama dan studi keislaman jika teori Gestalt tersebut diperkenalkan kepada para mahasiswa dan pemerhati studi keislaman antara lain: (a) pengalaman tilikan (insight) bahwa tilikan memegang peranan yang penting dalam perilaku. Dalam proses pembelajaran, hendaknya para mahasiswa dan pemerhati studi keislaman memiliki kemampuan tilikan yaitu kemampuan mengenal keterkaitan unsur-unsur dalam suatu obyek atau peristiwa, (b) pembelajaran yang bermakna (meaningful learning) yakni kebermaknaan unsur-unsur yang terkait akan menunjang pembentukan tilikan dalam proses pembelajaran. Makin jelas makna hubungan suatu unsur akan makin efektif sesuatu yang dipelajari. Hal ini sangat penting dalam kegiatan pemecahan masalah, khususnya dalam identifikasi masalah dan pengembangan alternatif pemecahannya. Hal-hal yang dipelajari para mahasiswa dan pemerhati studi keislaman hendaknya memiliki makna yang jelas dan logis dengan proses kehidupannya, (c) perilaku bertujuan (pusposive behavior) bahwa perilaku terarah pada tujuan. Perilaku bukan hanya terjadi akibat hubungan stimulus-respons, tetapi ada keterkaitannya dengan dengan tujuan yang ingin dicapai. Proses pembelajaran akan berjalan efektif jika para mahasiswa dan pemerhati studi keislaman mengenal tujuan yang ingin dicapainya, (d) prinsip ruang hidup (life space) bahwa perilaku individu memiliki keterkaitan dengan lingkungan dimana ia berada. Oleh karena itu, materi yang diajarkan hendaknya memiliki keterkaitan dengan situasi dan kondisi lingkungan kehidupan para mahasiswa dan pemerhati studi keislaman, (e) transfer dalam belajar yaitu pemindahan polapola perilaku dalam situasi pembelajaran tertentu ke situasi lain.

Dalam pandangan Gestalt, transfer belajar terjadi dengan jalan melepaskan pengertian obyek dari suatu konfigurasi dalam situasi tertentu untuk kemudian menempatkan dalam situasi konfigurasi lain dalam tatasusunan yang tepat. Judd menekankan pentingnya penangkapan prinsipprinsip pokok yang luas dalam pembelajaran dan kemudian menyusun ketentuan-ketentuan umum (generalisasi). Transfer belajar akan terjadi 
apabila para mahasiswa dan pemerhati studi keislaman telah menangkap prinsip-prinsip pokok dari suatu persoalan dan menemukan generalisasi untuk kemudian digunakan dalam memecahkan masalah dalam situasi lain.

Hubungan yang bercorak dialogis dan atau integratif antara agama, ilmu, dan budaya dapat dipahami bahwa beberapa sistem agama yang utama memberikan bermacam-macam keyakinan untuk melihat signifikansi kehidupan di dunia. Banyak ditemukan bahwa perbedaan muncul karena sensivitas pengamatan para pengamat yang tergantung pada tingkah laku, pengalaman, dan karakternya. Selanjutnya gestalt ini tumpang tindih hingga tidak dapat dibandingkan.

Seringkali fenomena tentang gestalt ini menghampiri hampir seluruh lini kehidupan. Adanya pemahaman terhadap agama Islam yang hanya dalam satu wajah Islam, akan menjadikan masalah serius dalam bermasyarakat. Islam yang dipahami hanya sebagai agama ansich akan menolak mentah-mentah terhadap upaya studi keislaman. Islam hanya dipahami sebatas rukun iman, rukun
Islam, syahadat seperti yang terjelma dalam jumlah kancing baju dalam tradisi baju koko Cina Tikim atau baju surjan Jawa yang berkancing depan lima buah menggambarkan rukun Islam, enam kancing lengan baju, tiga di lengan kanan dan tiga kancing baju lainnya di lengan kiri, serta satu kancing baju di bahu kanan dan satu kancing baju lainnya di bahu sebelah kiri yang menggambarkan syahadatain. Budaya jumlah kancing baju yang melestari sampai saat ini, membuat Islam hanya disakralkan, padahal Islam tidak terbatas pada sisi itu, Islam multifaced.

Begitu pula tatkala pengkajian Majelis Tafsir Al-Qur'an (MTA), dalam menafsirkan Alquran sebatas pengetahuan, tidak berani beranjak menuju penafsiran progresif, membuat para pengkaji alquran ini terpaku dan terjerembab dalam pemikiran tekstual, akibatnya, mereka tidak mampu bersinergi dengan kebutuhan, kondisi, dan budaya masyarakat era kontemporer. Berangkat dari dari kasus jamaah MTA dapat dicermati bahwa mereka begitu ketakutan terhadap upaya sekularisasi alquran. Menurut mereka, Alquran harus dipahami dalam kerangka berpikir pada zaman wahyu 
diturunkan. Mereka kembali menggunakan kacong (celana congklang), berjenggot, identitas kata sapaan dengan menggunakan ana dan antum, dan berdakwah door to door, yang meniru seperti apa yang dilakukan Nabi pada saat menyebarkan Islam pertama kali di periode Makkah. Masyarakat kini dibingungkan dengan gestalt, pemahaman bahwa agama yang didakwahkan secara door to door sebagaimana halnya budaya para sales parfum atau peralatan rumah tangga menawarkan barang dagangannya. Sangat ironis bila terjadi pemahaman seperti itu. Oleh karena itu, diperlukan pandangan universal terhadap keterkaitan agama, ilmu, dan budaya, sehingga kita tidak picik dalam menyikapi, mengaplikasikan, maupun menawarkan pemikiran tentang Islam.

\section{Upaya Integrasi Keilmuan}

Di sisi lain, jika perbincangan ini dikaitkan dengan ulüm al-dīn dan studi keislaman sebagai sarjana kontemporer juga dituntut untuk membawa gestalt ini pada dunia sains dan agama secara universal. Namun ini juga sering terkendala dengan masih minimnya pengetahuan dikalangan sarjana yang sering masih kebingungan, kacamata apa yang harus dipakai untuk melihat permasalahan sains dan agama. Belum lagi karena kurangnya pengetahuan dan pemahaman keilmuan, tidak tahu lagi cara membersihkan kacamata ini, harus menggunakan lap, dicuci dengan air, atau cukup dengan diuapi mulut. Banyak cara bisa dilakukan, tapi memilih cara dengan tepat, itu yang sering membingungkan. Oleh karena itu, cara pandang terhadap keilmuan yang berbeda-beda akan membuat hubungan antara ilmu pengetahuan dan agama itu menjadi bermacam-macam tipologi. Ada empat tipologi hubungan sains dan agama yang sering muncul diantaranya; konflik, independen, dialog, dan integrasi.

Pertama konflik. Pandangan konflik ini mengemuka pada abad ke19, dengan tokoh-tokohnya seperti: Richard Dawkins, Francis Crick, Steven Pinker, serta Stephen Hawking. Pandangan ini menempatkan sains dan agama dalam dua ekstrim yang saling bertentangan. Bahwa sains dan agama memberikan pernyataan yang berlawanan sehingga orang harus memilih salah satu di antara keduanya. Masing-masing menghimpun penganut dengan mengambil posisi-posisi yang 
berseberangan. Sains menegasikan eksistensi agama, begitu juga sebaliknya. Keduanya hanya mengakui keabsahan eksistensi masing-masing.

Pertentangan antara kaum agamawan dan ilmuwan di Eropa ini disebabkan oleh sikap radikal kaum agamawan Kristen yang hanya mengakui kebenaran dan kesucian Kitab Perjanjian Lama dan Perjanjian Baru, sehingga siapa saja yang mengingkarinya dianggap kafir dan berhak mendapatkan hukuman. Di lain pihak, para ilmuwan mengadakan penyelidikan-penyelidikan ilmiah yang hasilnya bertentangan dengan kepercayaan yang dianut oleh pihak gereja (kaum agamawan). Akibatnya, tidak sedikit ilmuwan yang menjadi korban dari hasil penemuan oleh penindasan dan kekejaman dari pihak gereja.

Contoh kasus dalam hubungan konflik yakni hukuman yang diberikan oleh gereja Katolik terhadap Galileo Galilei atas aspek pemikirannya yang dianggap menentang gereja. Demikian pula penolakan gereja Katolik terhadap teori evolusi Darwin pada abad ke-19 (Mahzar, 2004: 212) bahwa penolakan fundamentalisme religius secara dogmatis ini mempunyai perlawanan yang sama dogmatisnya di beberapa kalangan ilmuwan yang menganut kebenaran mutlak obyektivisme sains. Sebagai identifikasi yakni yang riil dapat diukur dan dirumuskan dengan hubungan matematis. Mereka juga berasumsi bahwa metode ilmiah merupakan satu-satunya sumber pengetahuan yang dapat dipercaya dan dipahami. Pada akhirnya, penganut paham ini cenderung memaksakan otoritas sains ke bidang-bidang di luar sains. Sedangkan agama, bagi kalangan saintis barat dianggap subyektif, tertutup dan sangat sulit berubah. Keyakinan terhadap agama juga tidak dapat diterima karena bukanlah data publik yang dapat diuji dengan percobaan dan kriteria sebagaimana halnya sains. Agama tidak lebih dari cerita-cerita mitologi dan legenda sehingga tidak ada kaitannya sama sekali dengan sains.

Barbour menanggapi hal ini dengan argumen bahwa mereka keliru apabila melanggengkan dilema tentang keharusan memilih antara sains dan agama. Kepercayaan agama menawarkan kerangka makna yang lebih luas dalam kehidupan. Sedangkan sains tidak dapat mengungkap rentang yang luas dari pengalaman manusia 
atau mengartikulasikan kemungkinankemungkinan bagi tranformasi hidup manusia sebagaimana yang dipersaksikan oleh agama (Barbour, 2006: 224).

Jelaslah bahwa pertentangan yang terjadi di dunia Barat sejak abad lalu sesungguhnya disebabkan oleh cara pandang yang keliru terhadap hakikat sains dan agama. Hal ini merupakan tugas manusia untuk merubah argumentasi mereka, selama ilmu pengetahuan dan teknologi yang mereka kembangkan itu bertentangan dengan agama. Sains dan agama mempengaruhi manusia dengan kemuliaan Sang Pencipta dan mempengaruhi perhatian manusia secara langsung pada kemegahan alam fisik ciptaan-Nya. Keduanya tidak saling bertolak belakang, karena keduanya merupakan ungkapan kebenaran.

Kedua independensi. Tidak semua saintis memilih sikap konflik dalam menghadapi sains dan agama. Ada sebagian yang menganut independensi, dengan memisahkan sains dan agama dalam dua wilayah yang berbeda. Masing-masing mengakui keabsahan eksisitensi atas yang lain antara sains dan agama. Baik agama maupun sains dianggap mempunyai kebenaran sendiri-sendiri yang terpisah satu sama lain, sehingga bisa hidup berdampingan dengan damai (Mahzar, 2004: 212). Pemisahan wilayah ini dapat berdasarkan masalah yang dikaji, domain yang dirujuk, dan metode yang digunakan. Mereka berpandangan bahwa sains berhubungan dengan fakta, dan agama mencakup nilai-nilai. Dua domain yang terpisah ini kemudian ditinjau dengan perbedaan bahasa dan fungsi masingmasing.

Analisis bahasa menekankan bahwa bahasa ilmiah berfungsi untuk melalukan prediksi dan kontrol. Sains hanya mengeksplorasi masalah terbatas pada fenemona alam, tidak untuk melaksanakan fungsi selain itu. Sedangkan bahasa agama berfungsi memberikan seperangkat pedoman, menawarkan jalan hidup dan mengarahkan pengalaman religius personal dengan praktek ritual dan tradisi keagamaan. Bagi kaum agamawan yang menganut pandangan independensi ini, menganggap bahwa Tuhanlah yang merupakan sumbersumber nilai, baik alam nyata maupun gaib. Hanya agama yang dapat mengetahuinya melalui keimanan. 
Sedangkan sains hanya berhubungan dengan alam nyata saja. Walaupun interpretasi ini sedikit berbeda dengan kaum ilmuwan, akan tetapi pandangan independensi ini tetap menjamin kedamaian antara sains dan agama.

Contoh-contoh saintis yang menganut pandangan ini di antaranya seorang Biolog Stephen Joy Gould, Karl Bath, dan Langdon Gilkey. Karl Bath menyatakan beberapa hal tentang pandangan independensi ini, yang dikutip oleh Ian G. Barbour (Barbour, 2006: 66). Menurutnya, Tuhan merupakan transendensi yang berbeda dari yang lain dan tidak dapat diketahui kecuali melalui penyingkapan diri. Keyakinan agama sepenuhnya bergantung pada kehendak Tuhan, bukan atas penemuan manusia sebagaimana halnya sains. Saintis bebas menjalankan aktivitas mereka tanpa keterlibatan unsur teologi, demikian pula sebaliknya, karena metode dan pokok persoalan keduanya berbeda. Sains dibangun atas pengamatan dan penalaran manusia sedangkan teologi berdasarkan wahyu Ilahi.

$$
\begin{aligned}
& \text { Barbour mencermati bahwa } \\
& \text { pandangan ini sama-sama } \\
& \text { mempertahankan karakter unik dari }
\end{aligned}
$$

sains dan agama. Namun demikian, manusia tidak boleh merasa puas dengan pandangan bahwa sains dan agama sebagai dua domain yang tidak koheren. Bila manusia menghayati kehidupan sebagai satu kesatuan yang utuh dari berbagai aspeknya yang berbeda, dan meskipun dari aspekaspek itu terbentuk berbagai disiplin yang berbeda pula, tentunya manusia harus berusaha menginterpretasikan ragam hal itu dalam pandangan yang lebih dialektis dan komplementer.

Ketiga, dialog. Pandangan ini menawarkan hubungan antara sains dan agama dengan interaksi yang lebih konstruktif daripada pandangan konflik dan independensi. Diakui bahwa antara sains dan agama terdapat kesamaan yang bisa didialogkan, bahkan bisa saling mendukung satu sama lain. Dialog yang dilakukan dalam membandingkan sains dan agama menekankan kemiripan dalam prediksi metode dan konsep. Salah satu bentuk dialognya adalah dengan membandingkan metode sains dan agama yang dapat menunjukkan kesamaan dan perbedaan.

Ian G. Barbour memberikan contoh masalah yang didialogkan ini dengan digunakannya model-model 
konseptual dan analogi-analogi ketika menjelaskan hal-hal yang tidak bisa diamati secara langsung. Dialog juga bisa dilakukan untuk menjawab pertanyaan-pertanyaan tentang ilmu pengetahuan yang mencapai tapal batas, seperti mengapa alam semesta ini ada dalam keteraturan yang dapat dimengerti? Ilmuwan dan teolog dapat menjadi mitra dialog dalam menjelaskan fenomena tersebut dengan tetap menghormati integritas masingmasing (Barbour, 2006: 32).

Dalam menghubungkan agama dan sains, pandangan ini dapat diwakili oleh pendapat Albert Einstein, yang mengatakan bahwa "Religion without science is blind, science without religion is lame." Tanpa sains, agama menjadi buta, dan tanpa agama, sains menjadi lumpuh. Demikian pula pendapat David Tracy, seorang teolog Katolik yang menyatakan adanya dimensi religius dalam sains bahwa intelijibilitas dunia memerlukan landasan rasional tertinggi yang bersumber dalam teks-teks keagamaan klasik dan struktur pengalaman manusiawi (Barbour, 2006: 76).

Penganut pandangan dialog ini berpendapat bahwa sains dan agama tidaklah sesubyektif yang dikira.
Antara sains dan agama memiliki kesejajaran karakteristik yaitu koherensi, kekomprehensifan dan kemanfaatan. Begitu juga kesejajaran metodologis yang banyak diangkat oleh beberapa penulis termasuk penggunaan kriteria konsistensi dan kongruensi dengan pengalaman. Seperti pendapat filosof Holmes Roston yang menyatakan bahwa keyakinan dan keagamaan menafsirkan dan menyatakan pengalaman, sebagaimana teori ilmiah menafsirkan dan mengaitkan data percobaan (Barbour, 2006: 80). Beberapa penulis juga melakukan eksplorasi terhadap kesejajaran konseptual antara sains dan agama, disamping kesejajaran metodologis. Dari uraian tersebut, dapat disimpulkan bahwa kesejajaran konseptual maupun metodologis menawarkan kemungkinan interaksi antara sains dan agama secara dialogis dengan tetap mempertahankan integritas masing-masing.

Keempat integrasi. Pandangan ini melahirkan hubungan yang lebih bersahabat daripada pendekatan dialog dengan mencari titik temu diantara sains dan agama. Sains dan doktrindoktrin keagamaan, sama-sama dianggap valid dan menjadi sumber 
koheren dalam pandangan dunia. Bahkan pemahaman tentang dunia yang diperoleh melalui sains diharapkan dapat memperkaya pemahaman keagamaan bagi manusia yang beriman (Mahzar, 2004: 213).

Mencermati pandangan ini, bahwa dalam hubungan integratif memberikan wawasan yang lebih besar mencakup sains dan agama sehingga dapat bekerja sama secara aktif. Bahkan sains dapat meningkatkan keyakinan umat beragama dengan memberi bukti ilmiah atas wahyu atau pengalaman mistis. Sebagai contohnya adalah Maurice Bucaille yang melukiskan tentang kesejajaran deskripsi ilmiah modern tentang alam dengan deskripsi Alquran tentang hal yang sama. Kesejajaran inilah yang dianggap memberikan dukungan obyektif ilmiah pada pengalaman subyektif keagamaan. Pengakuan keabsahan klaim sains maupun agama ini atas dasar kesamaan keduanya dalam memberikan pengetahuan atau deskripsi tentang alam.

Pemahaman yang diperoleh melalui sains sebagai salah satu sumber pengetahuan, menyatakan keharmonisan koordinasi penciptaan sebagai desain cerdas Ilahi. Seperti halnya ketika memperhatikan bagianbagian tubuh manusia dengan strukturnya yang tersusun secara kompleks dan terkoordinasi untuk tujuan tertentu. Meskipun Darwin melawan pandangan itu dalam teori evolusi yang mengangggap bahwa koordinasi dan detail-detail struktur organisme itu terbentuk karena seleksi alam dan variasi acak dalam proses adaptasi, namun dia sendiri mengakui argumen desain Ilahi, akan tetapi dalam anggapan sebagai penentu dari hukumhukum proses evolusi itu yang membuka kemungkinan variasi detail organisme tersebut, bukan dalam anggapan Tuhan sebagai perancang sentral desain organisme.

Ada beberapa pendekatan yang digunakan dalam hubungan integrasi ini. Pertama, berangkat dari data ilmiah yang menawarkan bukti konsklusif bagi keyakinan agama, untuk memperoleh kesepakatan dan kesadaran akan eksistensi Tuhan. Kedua, yaitu dengan menelaah ulang doktrin-doktrin agama dalam relevansinya dengan teori-teori ilmiah, atau dengan kata lain, keyakinan agama diuji dengan kriteria tertentu dan dirumuskan ulang sesuai dengan penemuan sains terkini. Lalu pemikiran 
sains keagamaan ditafsirkan dengan filasafat proses dalam kerangka konseptual yang sama. Demikian Barbour menjelaskan tentang hubungan integrasi ini (Barbour, 2006: 42).

Selanjutnya gagasan keilmuan yang integratif dan interkonektif dimunculkan oleh Amin Abdullah, terkait dengan tantangan perkembangan zaman yang sedemikian pesatnya yang dihadapi oleh umat Islam saat ini. Teknologi yang semakin canggih sehingga tidak ada lagi sekatsekat antar bangsa dan budaya, persoalan migrasi, revolusi IPTEK, genetika, pendidikan, hubungan antar agama, gender, HAM dan lain sebagainya. Perkembangan zaman mau tidak mau menuntut perubahan dalam segala bidang tanpa terkecuali pendidikan keislaman, karena tanda adanya respon yang cepat melihat perkembangan yang ada maka kaum musliimin akan semakin jauh tertinggal dan hanya akan menjadi penonton, konsumen bahkan korban di tengah ketatnya persaingan global. Menghadapi tantangan era globalisasi ini, umat Islam tidak hanya sekedar butuh untuk survive tetapi juga upaya untuk bisa menjadi garda depan perubahan. Hal ini kemudian dibutuhkan reorientasi pemikiran dalam pendidikan Islam dan rekonstruksi sistem kelembagaan di Perguruan Tinggi Agama maupun Perguruan Tinggi Umum.

Jika selama ini terdapat sekatsekat yang sangat tajam antara "ilmu" dan "agama" yang keduanya seolah menjadi entitas yang berdiri sendiri dan tidak bisa dipertemukan, mempunyai wilayah sendiri baik dari segi objekformal-material, metode penelitian, kriteria kebenaran, peran yang dimainkan oleh ilmuwan hingga institusi penyelenggaranya, maka tawaran paradigma integratifinterkoneksi yang melibatkan demensi Ulumuddin, al-Fikr al-Islamiy, dan Dirasat Islamiyyah berupaya mengurangi ketegangan-ketegangan tersebut tanpa meleburkan satu sama lain tetapi berusaha mendekatkan dan mengaitkannya sehingga menjadi "bertegur sapa" satu sama lain (Abdullah, 2007: 92-93). Hal inilah yang menjadi tolok ukur signifikansi dalam penerapan integrasi-interkoneksi dalam keilmuan sperti di UIN Sunan Kalijaga Yogyakarta (Zulfa, 2016). 


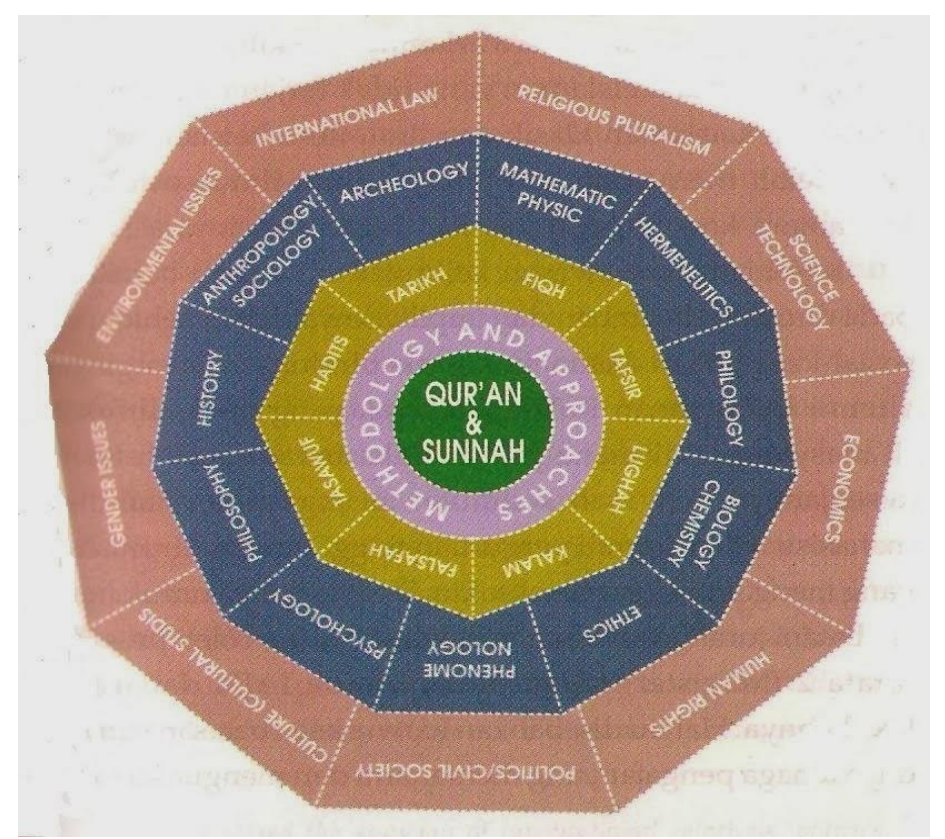

Gambar 2. Horizon Jaring Laba-laba Keilmuan Teoantroposentrik-Integralistik (Abdullah, 2007)

Sementara itu, sebagaimana yang terlihat dalam jaring laba-laba diharapkan dengan paradigma integratif-interkonektif akan terjadi perkembangan dalam ilmu keislaman, dimana tidak lagi terfokus pada lingkar 1 dan lingkar ke 2 tetapi juga melangkah pada lingkar ke 3 dan ke 4 . Selama ini pengajaran di perguruan tinggi agama masih berkutat pada lingkar 1 dan ke 2 dan masih baru akan memasuki lingkar ke 3 serta belum menyentuh pada lingkar ke 4. Jaring laba-laba ini menampakkan adanya pergerakan zaman dan kompleksitas persoalan masyarakat yang akan bisa diselesaikan dengan perkembangan ilmu-ilmu keislaman. Lingkar 1 dan 2 disebut sebagai Ulumuddin yang merupakan representasi dari "tradisi lokal" keislaman yang berbasis pada "bahasa" dan "teks-teks" atau nashnash keagamaan. Lingkar ke 3 disebut sebagai al-Fikr al-Islamiy sebagai representasi pergumulan humanitas pemikiran keislaman yang berbasis pada "rasio-intelek". Sedangkan lingkar ke 4 disebut Dirasat Islamiyyah atau Islamic Studies sebagai kluster keilmuan baru yang berbasis pada paradigma keilmuan sosial kritiskomparatif lantaran melibatkan seluruh "pengalaman" (experiences) umat manusia di alam historis-empiris yang amat sangat beranekaragam (Anshori, 2014: 90-108).

Pembatasan istilah Ulumuddin, al-Fikr al-Islamy dan Dirasat 
Islamiyah ini hanya akan mempermudah dalam pembahasan. Dalam pembagian ini Amin Abdullah merujuk pada perspektif sejarah perkembangan studi agama-agama yang telah melewati 4 (empat) fase, yaitu, lokal, kanonikal, kritikal dan global dari Keith Ward. Fase pertama, tahapan local. Semua agama pada era presejarah (Prehistorical period) dapat dikategorikan sebagai lokal. Semua praktik tradisi, kultur, adat istiadat, norma, bahkan agama merupakan fenomena lokal. Fase kedua, fase canonical atau propositional. Era agama-agama besar dunia (world religions) masuk dalam kategori tradisi canonical ini. Kehadiran agama-agama Ibrahimi (Abrahamic Religions), dan juga agama-agama di Timur yang pada umumnya menggunakan panduan Kitab Suci (the Sacred Text) merupakan babak baru tahapan sejarah perkembangan agama-agama dunia. Dalam Islam, fase ini corak keberagamaan yang scripturalistekstualis.

Fase ketiga, fase critical. Pada abad ke-16 dan 17, kesadaran beragama di Eropa mengalami perubahan yang radikal, yang terwadahi dalam gerakan
Enlightenment. Tradisi baru ini berkembang terus, yang kemudian membudaya dalam dunia akademis, penelitian (research), scholarly work dan wilayah intelektual pada umumnya. Dalam fase ini muncul keilmuan baru dalam Islam sebagaimana dalam lingkar ke 3 jaring laba-laba. Fase keempat adalah fase Global sebagaimana yang terjadi saat ini dan memunculkan keilmuan baru berikut juga metodenya yang lebih kritis dan tidak hanya terpaku pada rasio. Disini bisa terlihat pada lingkar ke 4 jaring laba-laba.

Lebih lanjut lihat M. Amin Abdullah, Mempertautkan 'Ulum aldin al-fikr al-islami dan dirasat islamiyah; sumbangan keilmuan Islam untuk peradaban global, disampaikan dalam Workshop Pembelajaran Inovatif Berbasis IntegrasiInterkoneksi, Yogyakarta, 19 Desember 2008. Kurikulum Agama Islam, penulis memadukan jaring labalaba dengan disokong oleh lima demensi piramida terbalik yang menggambarkan tujuan pembelajaran, materi, subjek dan objek, media dan evaluasi, serta lingkungan pembelajaran. Lima demensi tersebut sebagai kaki-kaki yang melandasi 
terselenggaranya keilmuan Islam, yang seluruh sisi-sisinya memancarkan sedangkan jaring laba-laba sebagai sisikemilau yang sangat menarik. Sisi-sisi sisi keilmuan yang harus dikaji dan diamond merupakan bidang keilmuan dikaitkan dengan tiga demensi yang dikaji, sedangkan kemilau Ulumuddin, al-Fikr al-Islamiy, dan Dirasat Islamiyyah (iman, ilmu, dan amal atau agama, ilmu dan budaya). Abdullah Darraz mengungkapkan bahwa Alquran bagaikan intan yang setiap sudutnya memancarkan cahaya yang berbeda dengan apa yang terpancar dari sudut-sudut yg lain. Dan tidak mustahil jika anda mempersilahkan orang lain memandangnya, maka ia akan melihat lebih banyak dari apa yang ia lihat (Darraz, 1960: 111).

Penulis menggambarkannya diamond itu menggambarkan hasil bentukan pemahaman atas sains, agama, dan budaya yang tergambar pada karakter sarjananya. Semakin banyak sisi-sisi diamond, akan menjadikannya bernilai sangat mahal. Artinya, semakin banyak kajian sains kontemporer yang dipadukan dengan agama Islam, maka semakin terlihat dedikasi keilmuan Islamnya. Yang tentunya sangat berpengaruh pada karakter para sarjananya. Ikatan ini merupakan sebuah sistem yang kuat yang tak dapat dipisah-pisahkan.

sebagaimana sebuah diamond (berlian)

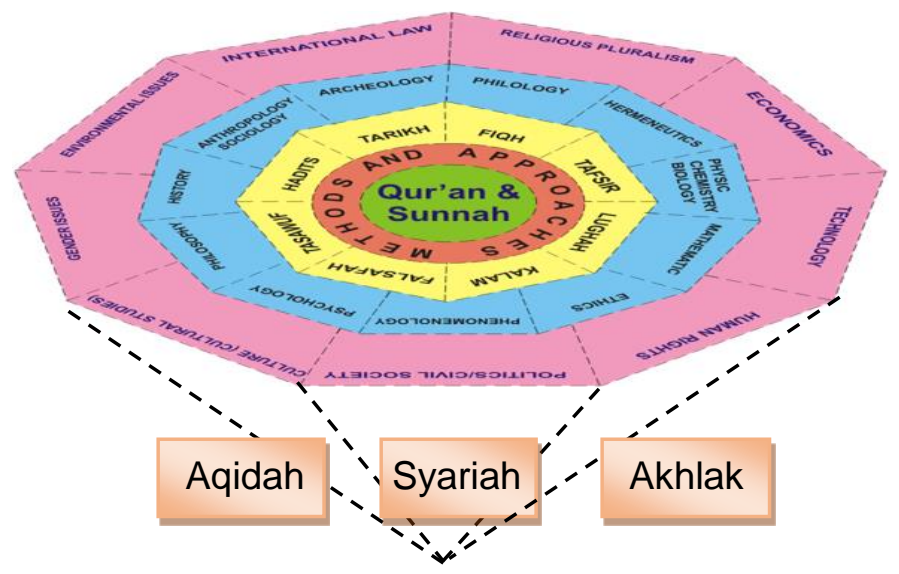

Gambar 3. Learning Diamond Oriented

Oleh karena itu, dalam pengajaran Agama Islam selalu ditanamkan untuk tidak merasa takut akan kajian dan penelitian apa pun yang berkaitan dengan sains dan agama. Justru sains memberikan 
makna, penguat, dan dedikasi terhadap agama, utamanya agama Islam. Islam itu benar yang datang dari yang Maha Benar. Islam diuji dengan ilmu apa pun, akan tetap menunjukkan kebenarannya. Dalam jajaran agama, hanya Islam yang tetap eksis menampakkan keberiringan agama dengan sains. Dan semakin sains menampakkan kemajuannya, di situlah Islam menggoreskan sisi diamond lainnya yang tentunya menambah kemilau dan mahalnya diamond. Untuk itu, institusi Pendidikan Tinggi Agama dengan dukungan sistem diamond keilmuan Islam, di dalam kurikulumnya harus mampu menghubungkan antara agama, ilmu, dan budaya secara terintegrasi dan terkoneksi sebagai satu sistem untuk mengantarkan para sarjana muslimnya memiliki karakter yang mumpuni.

\section{PENUTUP}

Dari uraian di atas dapat disimpulkan bahwa terdapat realitas bahwa sains dan agama dipandang secara terpisah. Sains tidak dapat dikaji dan diuji dengan keilmuan agama dan sebaliknya agama tidak mampu di kaji dan diuji dengan sains. Ada empat tipologi hubungan sains dan agama yang sering muncul diantaranya; konflik, independen, dialog, dan integrasi. Langkah integrasi merupakan upaya terkini untuk menegursapakan antara keduanya apalagi dikoneksikan dengan keilmuan yang berbeda-beda. Pada akhirnya justru tampak kecemerlangan fungsi sains dan agama sebagaimana berlian. Semakin banyak sudut dan sisi yang ada pada berlian justru memunculkan kilauan yang menakjubkan dan tentunya lebih bernilai tinggi.

\section{UCAPAN TERIMA KASIH}

Terima kasih kepada redaksi Humanika yang telah memuat artikel ini, semoga bermanfaat.

\section{DAFTAR PUSTAKA}

Abdullah, M. Amin dkk. 2007. Islamic Studies dalam Paradigma Integrasi-Interkoneksi. Yogyakarta: UIN Suka Press. Anshori dan Zaenal Abidin. 2014. Format Baru Hubungan Sains Modern dan Islam (Studi Integrasi Keilmuan atas UIN Yogyakarta dan Tiga Uinversitas Islam Swasta sebagai Upaya Membangun Sains Islam Seutuhnya Tahun 2007-2013). Profetika, Jurnal Studi Islam, Vol. 15, No. 1, Juni. Hal. 90-108. Journals.Ums.Ac.Id/Index.Php/P 
rofetika/

Article/Viewfile/1969/1382.

Ahmad, Saiyad Fareed dan Saiyad Salahuddin Ahmad. 2008. 5 Tantangan Abadi terhadap Agama. Alih bahasa Rudi Syah Alah. Bandung: Mizan.

Al-Faruqi, Ismail Raji. 1995. Islamisasi Pengetahuan. Alih bahasa Anas Mahyudin. Bandung: Pustaka.

Barbour, Ian G. 2006. Issu dalam Sain dan Agama. Terj. Damayanti dan Ridwan. Yogyakarta: UIN Sunan Kalijaga.

Darraz, Abdullah. 1960. Al-Naba' al-

'Azhîm. Mesir: Dar Al-'Urubah.

Gredler, M.E.Bell. 1991. Belajar dan

Membelajarkan. Jakarta: Rajawali.

Mahzar, Armahedi. 2004. Revolusi Integralisme Islam. Bandung: Mizan.

Mulyanto. 2006. Ilmu Tanpa Agama Pincang, Agama Tanpa Ilmu Buta (Mengungkap Misteri Tuhan dan Keimanan Einstein). Bandung: Dzikra

Mustofa, M. Lutfi dan Helmi Syaifuddin $\quad$ (ed.). 2007. Intelektualisme Islam; Melacak Akar-akar Integrasi Ilmu dan Agama. Malang: Aditya Media.

Roston III, Holmes. 1987. Science and Religion: A Critical Survey. New York: Random House Inc.

Roston III, Holmes. 2006. Ilmu dan Agama Sebuah Survai Kritis. Yogyakarta: UIN Sunan Kalijaga.

Wasim, Alef Theria. 2000. "Minoritas dan Mayoritas; Pendekatan
Psikologis-Sosial Keagamaan," dalam Amin Abdullah dkk. (ed.). Antologi Studi Islam; Teori dan Metodologi. Yogyakarta: Sunan Kalijaga Press.

Zulfa, Laila Ngindana. 2016. Integrative-Interconnective Approach in Islamic Studies (Crtical Studies on M. Amin Abdullah's Thought). Proceeding of the 2 nd International Seminar and Conference on Global Issues (ISCoGI) 2016: European and Asian in the Age of Globalization: Cooperation and Challenge Wahid Hasyim University, Semarang, Indonesia. Nov. 25-26. Paper No. B.12 ISBN 978-602-8273-57-2.

B.12.1-

B.12.7.https://publikasiilmiah.un wahas.

ac.id/index.php/ISC/article/.../17 56. 